551. $513: 523.74$

\title{
On the Relation between Solar Activity and General Circulation in the Atmosphere
}

\author{
by \\ T. Asakura \\ Meteorological Research Institute, Tokyo \\ and A. Katayama \\ Tokyo District Meteorological Observatory, Tokyo \\ (Received May 20, 1958)
}

\begin{abstract}
Relation between solar activity and variations of the general circulation is investigated by using data during winter of 1946-1956. $\mathrm{K}$-and $\mathrm{C}_{i}$-index, which are measures of geomagnetic activity, are used to represent solar activity. As indices to represent a hemispheric flow pattern, kinetic energy of 5-day mean north-south wind component and amplitudes of each harmonic wave along $50^{\circ}$ latitude circle are used. Summarizing the results, ten days or so after an intense sporadic outburst of corpuscular emission from the sun, a circulation pattern seems to change into a low index type and heat exchange along the meridian is intensified. A typical example of intense corpuscular emission and the subsequent change of the circulation pattern was observed in the middle of February 1958, when a recordbreaking intensity of aurora was observed in many countries including abnormally low latitudes.
\end{abstract}

\section{Introduction}

Recently, studies on the relations between solar activity and various meteorological elements seem to have been promoted from a revised point of view.

This is mainly due to the increasing network of upper air observations and rocket observations and also to the fact that the physical meaning of phenomena on the solar surface has been clarified.

There is no room for doubt that solar radiation supplies energy in the terrestrial atmosphere, but whether variations of energy coming from the sun deform tropospheric air motion and distribution of air temperature seems to be left undecided. In fact, variation of total energy coming from the sun, expressed by a solar constant, is less than 0.3 percent of solar constant which is within the error of observation. However, much attention has recently been given to the fact that in the period of 
high solar activity, near ultra violet radiation seems to be strengthened and that corpuscular radiation which is concentrated in the auroral zones around the pole may have the same order of energy as a solar constant.

The former may disturb the production of ozone in the upper ozonosphere and the latter may possibly give rise to temperature rise at the rate of $1000^{\circ} \mathrm{c}$ per minute at $100 \mathrm{~km}$ height, as mentioned by London, (1956) which, however, seems to the present writers to be a case of overestimation.

Hitherto, the physical process of how the solar activity is related to the weather has been considered hypothetically by many workers as follows: Such an energy input into the upper atmosphere (above $80 \mathrm{~km}$ ) changes the circulation of the ionosphere or the upper mesosphere, and then, this effect is transferred downward through the stratosphere, to the troposphere, though its mechanism is not clear, and acts as a trigger action to variations of tropospheric circulation. In addition, K. Takahashi and T. Asakura (1954) have pointed out that a temperature change in the troposphere caused by a variation of solar radiation is too small to explain an observed one and ascribed it to a varied austausch coefficient which might be caused by solar activity in some ways. So, we are much interested in whether any significant relation exists or not between solar activity and tropospheric disturbance.

Though it is a very important problem to justify previous hypotheses by direct physical approach, our present knowlege of solar physics and the upper atmosphere is too poor to do it. Therefore, as a first step, we attempt to establish the relationships between them statistically.

\section{Representation of solar activity and of the state of general circulation in the troposphere}

What meteorological or solar indices are to be used is an important porblem to our study. Sun-spot relative number is in general used for the representation of the solar activity, though its physical meaning is vague. On the other hand, an index of solar flare is a better measure to express a variation of corpuscular radiation and near ultra-violet radiation. Unfortunately, a direct index of the intensity of solar flare is not available for the present as Ward (1956) has pointed. So, we used indices of geomagnetic activity, such as $K_{p} *$ ) and $C_{i}$,**) which are considered to express an intensity of solar corpuscular radiation.

$K$-index observerd at Kakioka in Japan and $C_{i}$ are used for our study, but use of $K$-index at a station instead of $K_{p}$-index will not induce an enormous error to our conclusion as $K$-index has a high correlation (0.9-1.0) with $K_{p}$-index.

*) Each magnetic observatory devised a scale which ranges from 0-9, to measure the extreme range of disturbance field of the elements during each of the eight 3-hour periods in the GMT day. Daily $K$-index is represented by a series of eight $K$-indices to that day. Planetary $K_{p}$-index is the mean $K$-index, from 12 observations between geomagnetic latitudes 47 and 63 .

**) At each magnetic observatory, its daily magenetic record is classified as 0 (quiet), 1 (moderatoly disturbed or disturbed) or 2 (very disturbed) according to the scale proposed by Schmidt in 1905 . This is geomagnetic character figure $C . C_{i}$ is mean $C$, from many world geomagnetic observations. 
State of general circulation in the troposphere is roughly expressed in terms of high or low index.

High index is characterized by a prevailing zonal flow and a weak heat exchange along the meridian.

Low index has the character of prevailing meridional flow and a severe heat exchange along the meridian. Thus, an intensity of meridional flow has a close relationship with the state of general circulation and with the heat exchange between high and low latitudes, so the square of meridional wind speed is used as an index of a general circulation.

Index $A$ is defined as a mean of $\overline{V_{g}^{2}}\left(V_{g}\right.$ : geostrophic meridional flow) along latitude circle of $50^{\circ} \mathrm{N}$ at $500-\mathrm{mb}$ level. Namely, $Z$ (5-day mean height of $500 \mathrm{mb}$ along $50^{\circ}$ latitude circle) is expanded into six terms by using harmonic analysis:

$$
Z=A_{0}+\sum_{n=1}^{5} A_{n} \cos \left(n \lambda+\delta_{n}\right)
$$

Shorter waves are not taken here, because longer waves seem to be able to express roughly a 5-day mean flow pattern. $V_{g}^{2}$ is calculated by using geostropic relation.

$$
V_{g}^{2}=\left(\frac{g}{f} \frac{\partial z}{R \cos \theta \partial \lambda}\right)^{2}=\frac{g^{2}}{f^{2} R^{2} \cos ^{2} \theta}\left(\frac{\partial z}{\partial \lambda}\right)^{2}
$$

$R$ : radius of the earth, $\theta:$ Latitude, $f$ : Coriolis parameter, $g$ : acceleration of gravity, $\lambda$ : longitude. When eq. (2) is integrated along latitude circle using eq. (1), index $A$ is defined as follows :

$$
A=\frac{g^{2}}{2 f^{2} R^{2} \cos ^{2} \theta} \sum_{n=1}^{5} n^{2} A_{n}^{2}
$$

where $A_{n}$ is the amplitude of the harmonic wave as defined eq. (1). We wish to emphasize here that an index $A$ is not only a good measure of austausch coefficient but also a measure of atmospheric flow pattern.

Furthermore, amplitudes of each harmonic wave defined by eq. (1) are used for the representation of the general circulation. Amplitudes of wave number one and two are considered as a good index of the general circulation as LA SEuR (1954) and Y. ARAI (1958) have asserted.

\section{Statistical investigation on the relation between solar activity and variation of the general circulation}

As has been described in the previous section, $K$-index and $C_{i}$-value are used for the representation of solar activity, and $A$-index $\overline{\left(V_{g}^{2}\right)}$ and amplitudes of each harmonic wave are used for the representation of the state of the general circultion, and these indices are all 5-day means during the winter season (December, January, Feburuary and befor half of March) from 1946 to 1956.

To study whether the sporadic input of energy in the upper atmosphere can bring about any disturbance to a tropospheric circulation, relation between $K$-index and $A$-index is investigated by means of the key day test after CHreE (1913). 
Frequency distribution of 5 -day mean $K$-indices is approximately a normal distribution. Dividing it into five equal areas, we can get two groups of high $K(\geqq 22)$ and of low $K(\leqq 13)$ and each group contains twenty cases.

Summing arithmetically the

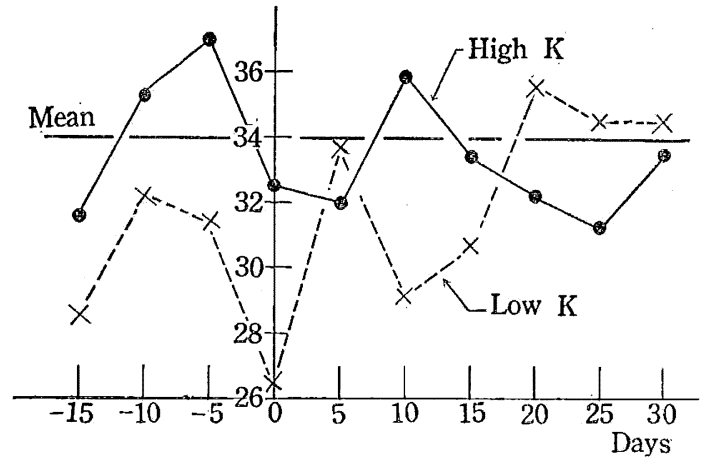

Fig. 1. Mean variations of $A$-index $\left(\overline{\left.V_{g}^{2}\right)}\right.$ before and after a key day in a case of high $K$ and of low $K$-index. Maximum difference of $A$-index between high $K$ and low $K$-index appears ten days after a key day (unit of ordinate : $2.2 \times 10^{4} \mathrm{~cm}^{2} / \mathrm{sec}^{2}$ ). value of $A$-index before and after the key days in a group of high $K$ and of low $K$, the means of $A$-index in cases of high $K$ and of low $K$ are obtained as shown in Fig. 1. As seen in this figure, both $A$-indices before the key day seem to change in parallel and periodically, but after the key day, they change in an opposite phase converging to a mean value in about a month after the key day. This result seems to suggest that there is some possibility of disturbing the tropospheric circulation about ten days later when strong corpuscular matter is emitted from the sun.

To study more qualitatively the relation between them, lag correlations are calculated between $\partial K / \partial t$ and $A$-index, where $\partial K / \partial t$ is calculated by subtracting 5-day mean $K$ on a key day from that of five days before. When $(\partial K / \partial t)>0$, an input of energy in the upper atmosphere would be considered to increase and when $(\partial K / \partial t)<0$, the reverse.

Fig. 2 is the result of the lag correlations and shows that the maximum correlation appears ten days after the key day, but no definite conclusion can be drawn on account of its too poor correlation, i.e. 0.15. In this case, the data when $\partial K / \partial t$ is negative were contained. However, to study the effect of sporadic heating in the upper atmosphere, the data when $K$-index increases suddenly must be used.

So the correlation is recalculated by correlating positive $\partial K / \partial t$ and

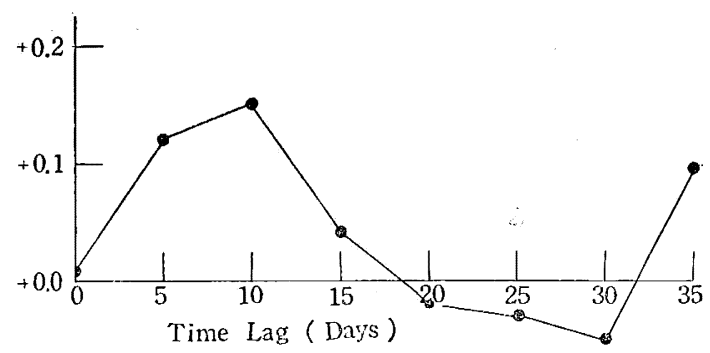

Fig. 2. Time lag correlation between $A$-index and $\partial K / \partial t$. Maximum value appears ten days after a key day with a poor correlation of 0.15 . variation of $A$-index referred to a value of five days before when positive $K$-tendency is taken. As easily seen in Fig. 3 , the correlation has a maximum value of 0.31 ten days later, which is similar to the previous result though its value is different. By statistical test, correlation coefficent of 0.31 is significant on the $10 \%$ level of significance. 
From these results, we may conclude that $A$-index (measure of austausch along the meridian) increases about ten days later when sporadic heatings (suggested by high $K$-index) are given in the upper atmosphere.

Furthermore, to study the relation between the tropospheric circulation and geomagnetic acitivity, the key day test is used for amplitudes of each harmonic wave defined by eq. (1) and international geomagnetic character figure $\mathrm{C} i$.

The amplitude of each harmonic wave is said to be correlated well with a tropospheric flow pattern.

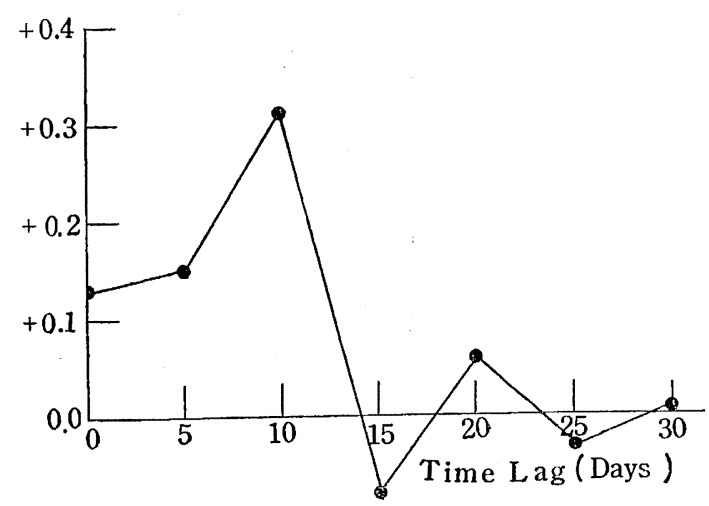

Fig. 3. Time lag correlation between $A$-index and the positive value of $\partial K / \partial t$. The correlation has a maximum value of 0.31 ten days after a key day, which is significant on the $10 \%$ level of significance. When an amplitude of wave number one $\left(A_{1}\right)$ in westerlies increases, a center of circumpolar circulation far from the pole and the hemispheric flow pattern becomes a high index type as shown by LA SEAUR (1954). Ridges of wave number two remain quasi-stationally where a blocking high often appears. So an increase of amplitude of wave number two $\left(A_{2}\right)$ is considered to correspond with an increase of blocking activity.

Y. ARAI (1958) has pointed out that three months mean and five-day mean of $A_{1}$ (amplitude of the first harmonic) correlated reversely with those of a relative sun spot number $R$ and $A_{2}$ positively correlated with $R$. Thus the low index type of flow pattern seems to prevail in a high solar activity.

Selecting a key day when $C_{i}$ increases by more than 1.0 per day as SHApIRo (1954) has employed, twenty-nine cases are obtained. Amplitudes of each harmonic wave before and after the key day are arithmetically added and averaged for every two days, which are estimated by an interpolation of 5-day mean. Fig. 4a-4d are the result of this computation.

Borken lines in these figures show the mean values for each wave's amplitude. $A_{1}$ has a nearly constant value, which is larger than the mean before and after the key day, but decreases suddenly to its mean value during the ten to fifteen days after the key day. On the other hand, $A_{2}$ increases linearly after the key day, though it keeps low values before it, and reaches its maximum value about ten days after the key day, and then it decreases exponentially to its mean value.

Variations of $A_{3}$ and $A_{4}$ are very similiar to those of $A_{2}$ and $A_{1}$ respectively but they are not significant statistically. However, variations of $A_{1}$ and $A_{2}$ after the key day are significant. 'That is, Student' t-tests are performed for $\Delta \overline{A_{1}}\left(\overline{A_{1}}\right.$ (key day +15 days $)-\overline{A_{1}}$ (key day) $=-99$ feet) and $\Delta \overline{A_{2}}\left(\overline{A_{2}}\right.$ (key day +10 days $)-\overline{A_{2}}$ (key day $=72$ feet) and we found both of them are significant on the $5 \%$ level of significance. 
Vol. IX No. 1

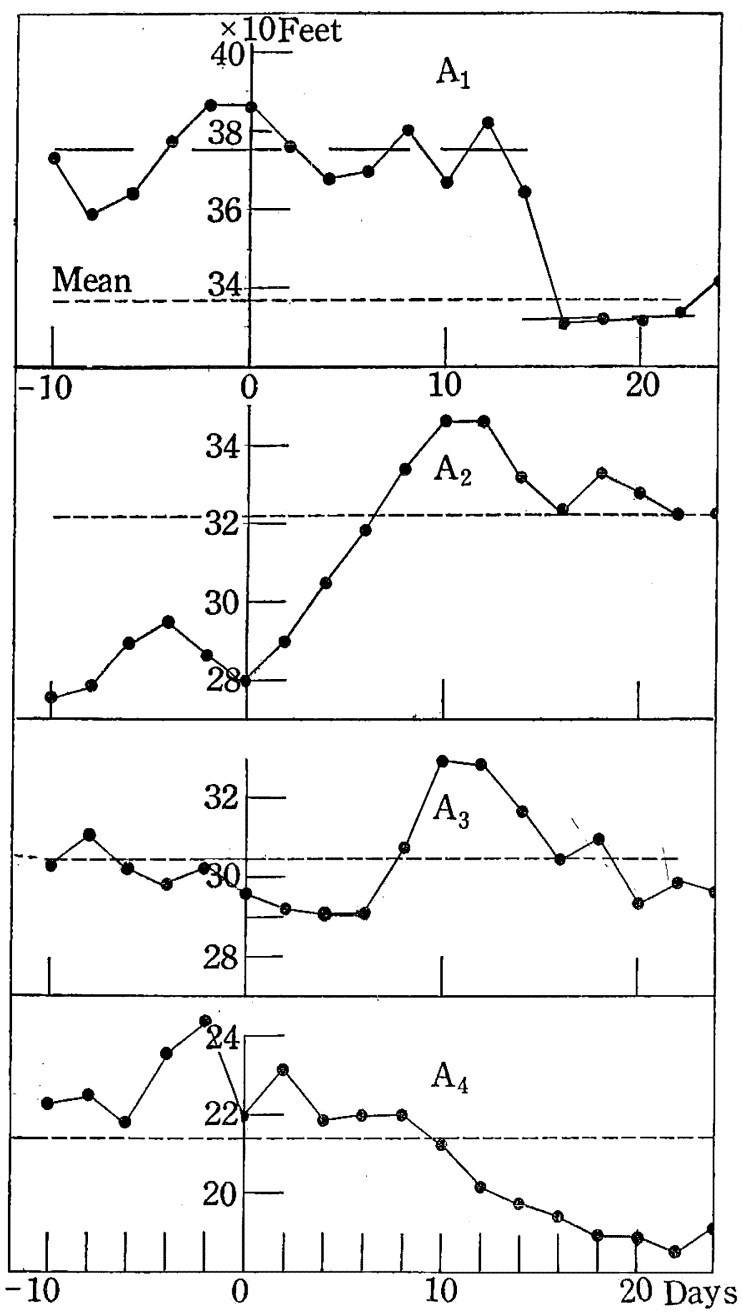

Fig. 4. Mean variations of amplitudes of each harmonic wave, when a geomagnetic activity $C_{i}$ increases 1.0 per day. $A_{1}$ has a decreasing tendency and $A_{2}$ has an increasing tendency about ten or fifteen days after $C_{i}$ increases 1.0 per day. These results are significant on the level of $5 \%$ level of significance.

Then, we may conclude statistically that ten days or so after the key day, $A_{1}$ is apt to decrease and $A_{2}$ to increase, which is a typical type of low index of the general circulation.

Strictly speaking, it is too much to say that a tropospheric circulation becomes low index type only by variations of $A$-index, $A_{1}$ and $A_{2}$ along the $50^{\circ}$ latitude circle. Then, in order to clear out variations of hemispheric flow pattern after the key day, a composite height tendency chart is constructed by subtracting 5 -day 
mean $500 \mathrm{mb}$ height at each grid point on a key day from that of height on ten days later.

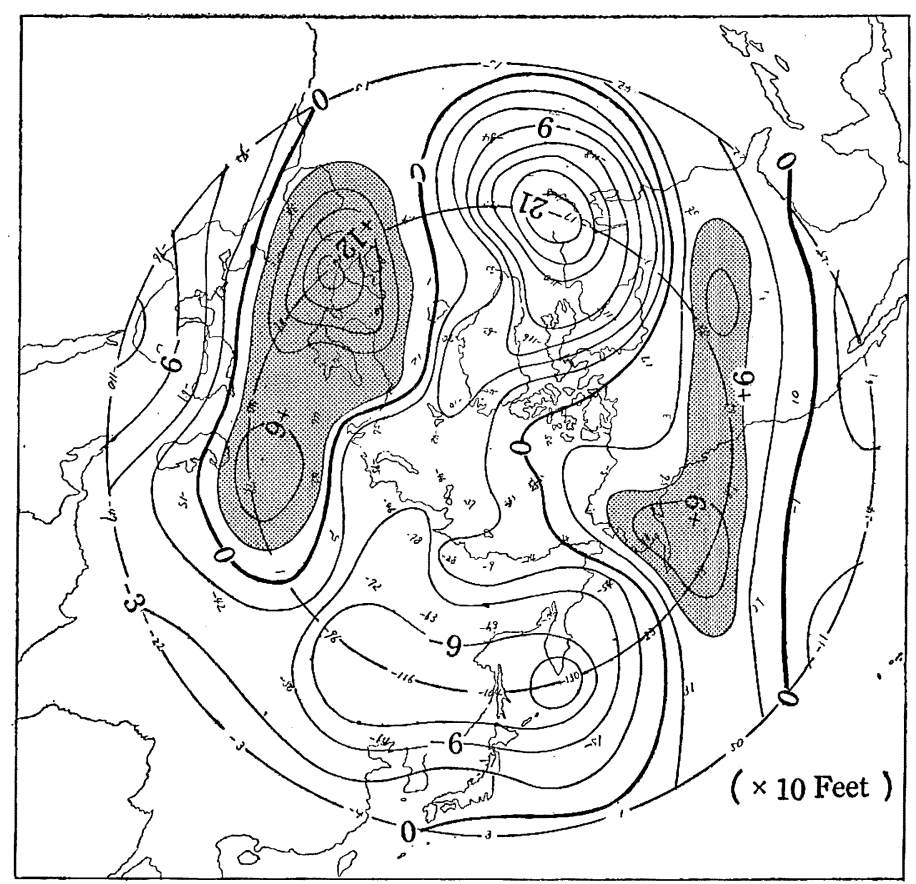

Fig. 5. Mean height tendency of 5-day mean $500 \mathrm{mb}$ chart ten days after a key day. Ten days after a key day, the height of 5-day mean $500-\mathrm{mb}$ has a rising tendency near Alaska and England where a blocking high often appears and has a falling tendency near East Asia and the east coast of America where cold air often bursts along a trough. This seems to show that the hemispheric flow pattern is changing into a low index type.

Fig. 5 is the composite height tendency chart thus constructed and shows two distinct regions of positive height tendency and negative height tendency. The former is situated in Alaska and near England where a blocking high often appears, and the latter is situated in East Asia and in the east coast of America where cold air often bursts along an anchor trough. That is, ten days after a severe corpuscule radiation is emitted from the sun, bursts of cold air along anchor throughs situated near Asia and the North American continent are apt to take place and at the same time, the blocking activity in the neighbourhood of the west coast of America and the west coast of Europe is strengthened. And thus, the pattern of tropospheric circulation would be changing into the low index type about ten days or so after a severe corpuscular emission reaches the upper atmosphere.

\section{Conclusions and further remarks}

Our tentative conclusions are as follows: 
1) $A$-index $\left(\overline{V_{g}^{2}}\right)$, which is a measure of heat exchange along the meridian and a measure of the circulation pattern, increases about ten deys or so after an intense corpuscule emitted from the Sun reaches the upper atmosphere.

2) The amplitude of wave number one in westerlies along $50^{\circ}$ Latitude defined by eq. (1) decreases rapidly in ten days or so after $C i$ increases by more than 1.0 per day. This means that the center of a circumpolar circulation approaches the pole and that the zonal westerlies are weakened.

3) The amplitude of wave number two increases and has a maximum value ten days or so after $\mathrm{Ci}$ increases by more than 1.0 per day. This variation of amplitude is closely connected with the blocking activity in westerlies.

4) Circulation pattern seems to change into a low index type about ten days after $\mathrm{C} i$ becomes more than 1.0 per day. These results are all significant from the statistical point of view.

Summarizing these results, ten days or so after an intense sporadic outburst of corpuscular emission from the sun, the state of the general curculation changes into the low index type which causes an intense heat exchange between high and low latitudes.

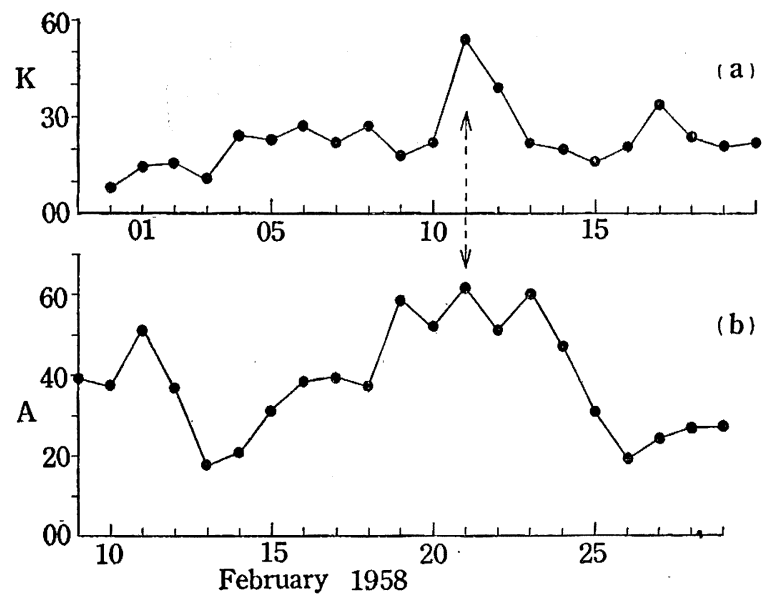

Fig. 6. Daily variation of $A$-index following a recordbreaking intensity of aurora was observed on 11 Feb. 1958. $A$-index attaines its maximum value in ten days after $K$-index suddenly increased. (upper $K$-index. bottom $A$-index)

A record-breaking intensity of aurora was observed in many countries on February 11,1958 just after these results were obtained. $A$-index in this special case varied in the same way as our conclusion(Fig. 6). Though these facts seem to support the conclusion of this paper, statistical investigation using aerological data as high as possible is considered to be important till the physical process of downward transfer of energy, which is input by solar activity, is clarified. Especially, study on the time lag of the responsibility of atmospheric disturbance for solar activities would afford an important clue to the mechanism described above. 
Acknowledgement-The author would like to express his hearty thanks to Dr. $K$. TAKAHASH and to members of colloquium of solar activity for their guidance and encouragement throughout the course of this study.

\section{References}

ArAI, Y., 1958: Charactaristics of long waves in westeries related to solar activity. Journ. Met. Soc. Japan, 36, 46-54.

Chrse, C., 1913: Some phenomena of sunspots and terrestrial magnetism at Kew Observatory. Phil. Trans. Roy. Soc. London, 212, 75-116.

High Altitude Observatory, 1956: Notes from cross-field seminar on possible responses of terrestrial atmospheric circulation to changes in solar activity. Techn. Rep. 1, Inst. Solar Terrestrial Research.

LA SEUR, N.E., 1954: On the asymmetry of the middle-latitude circumpolar current, J. Meteor., 11, 43-57.

Takatashi, K. and T. Asakdra, 1954: Relation of the sun and to weather. Journ. Met. Soc. Japan 32, 290-302 (in Japanese).

WARD, F. W., 1956: Solar, geomagnetic, and ionospheric phenomena as indices of solar activity. Geophys. Research Pap. 54, Air Force Cambridge Research Center. pp. 76.

Woodbridge, D. O., T. W. Pohrte, and N. Macdonald, 1957: A possible effect in $300 \mathrm{mb}$ circulation related to solar corpuscular emission. Techn. Rep. 3, Inst. Solar Terrestrial Research. High Altitude Obs.

Woodbridge, D. O., T. W. Pohrte, and N. Maddonald, 1957: A possible solar effect on wind patterns at high altitudes. Techn. Rep. 4, Inst. Solar-terrestrial Research, High Altitude Obs.

Shapiro, R., 1954: A possible solar-weather effect. J. Meteor. 11, 424-425.

SHAPIRD, R., 1956: Furtherevidence of a solar-weather effect. J. Meteor. 13, 335-340.

\section{太陽活動と大気 環流との関係}

朝倉正, 片山昭

太陽活動と大気㻴流との関係は古くから研究されているが，最近飞なつて太陽面現象の物理的意味が 解明されはじめ，大気環流や超高層の構造す次第飞分つてきたので新しい镜点からこの問題が取上げられ る傾向飞ある。1956 年 6,7 月飞米国コロラド大学で開かれたぜミナールとよると微粒子輻射とよつてオー ロラ帯の上層では太陽常数に匹敵するエネルギーの授与があり,見積り方に閣題があるが, 1 分間に $1000^{\circ} \mathrm{C}$ の年温の可能性が示された。また Solar flare が生ずると同時飞紫外部輻射が強められ光化学的飞生成さ れるオゾン㬐上部のオゾン量が変動する。このような一連の現象が 80 籼以上の大気環流を乱し，何らかの

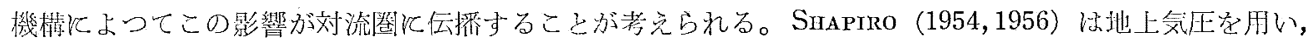
WOODBRIDGE (1957) は $300 \mathrm{mb}$ の天気図を用い，強い徽粒子輻射があると地上では 10 数日，300 mb では 
8 日程度たつて影響があらわれることを統計的と確かめている。また，高橋 (浩) 博士は太陽活動炕つて あたらされる温度変化を量的飞説明するには太陽輻射の変化だけでは不光分で交换係数の変化を考兄に入 れる必要性を示した。熱の交换係数の変動は南北の乱れの度合によつて示すことができる。また南北の乱 れの度合は緯度圈飞そつて平均した南北流のェネルギー（A-index）や偏西風帯 $\left(50^{\circ} \mathrm{N}\right)$ の波数 1,2 の 長波の振幅 $\left(\mathrm{A}_{1}, \mathrm{~A}_{2}\right)$ 飞よつてもあらわすことができる。太陽活動の指標として半旬平均地磁気活動度 $\mathrm{K}$-index と $C_{i}$ を用い, 大気環流の指標として冬期（1946-56 年，12月一- 月）半旬 $500 \mathrm{mb}$ 天気図の A-index や， $\mathrm{A}_{1} ， \mathrm{~A}_{2}$ を用いて相互の関係を統計的にしらべつぎの絬果を得た。

強い微粒子輻射が太陽面から放出されてやく 10 日ないし15 日たつと 1) A-index ( $\left.\overline{V g^{2}}\right)$ は增大し 2) 波数 1 の振幅 $\mathrm{A}_{1}$ は減少し 3）波数 2 の振幅 $\mathrm{A}_{2}$ は增大する。

すなわち, 強烈な微粒子輻射飞よつて上層にエネルギーがあたえられてやく10日向たつと対流圈の南 北交換が眭になり, 大気環流はいわゆる低示数型飞なる傾向が生ずる。かかる場合, 半旬 $500 \mathrm{mb}$ 天気図 を用いて, key day から 10 日後の高度傾向をしらべると, 寒気の吹出しやすい東アジアや東部アメリカ の高度は減少し, ブロッキング高気压がしばしば発生するアメりカ西海岸と西ヨーロツパの高度は增加す る傾向を示している。これも大爷の流れが低示数型炕変化することを物語るすのであるう。 